\title{
German hospital capacities for prolonged mechanical ventilator weaning in neurorehabilitation - results of a representative survey
}

\author{
Thomas Platz ${ }^{1,2,3^{*}}$ D, Andreas Bender ${ }^{1}$, Christian Dohle ${ }^{1}$, Anna Gorsler ${ }^{1}$, Stefan Knecht ${ }^{1}$, Joachim Liepert ${ }^{1}$, \\ Thomas Mokrusch ${ }^{1}$ and Michael Sailer ${ }^{1}$
}

\begin{abstract}
A brief survey among members of the German Neurorehabilitation Society aimed to document the hospital capacities ("beds") for prolonged weaning from a mechanical ventilator for patients with neuro-disabilities that require simultaneous multi-professional neurorehabilitation treatment. Sixty-eight institutions declared to have capacities with a broad distribution across Germany and its federal states. Overall, 1094 "beds" for prolonged weaning (and neurorehabilitation) were reported, 871 together with further information regarding their identification and hence regional location. These units had on average 16.1 beds for prolonged weaning (95\% confidence interval 12.6 to 19.6) with a range from 2 to 68 beds per organization. The data indicate substantial capacities for the combined prolonged weaning and neurorehabilitation treatment in Germany. For most "beds" included in this analysis a basic validation was possible. While a reasonable coverage of these specialized service capacities by the survey is likely, the number reported could still be biased by underreporting by non-response. Both the broad variation of number of "beds" for prolonged weaning per unit and their unequal geographical distribution across federal states (per capita rate) warrant a more refined follow-up survey that will provide insights into reasons for the observed pattern of variation for these specialized hospital capacities.
\end{abstract}

Keywords: Neurorehabilitation, Weaning, Neuro-disabilities, Hospital capacity

\section{Introduction}

Weaning is the medical process of withdrawing ventilator support. Prolonged weaning describes a situation of initial weaning failure, i.e. when more than three spontaneous breathing trials (SBT) or 7 days from the first SBT are required, and hence prolonged weaning care [1]. In specialized pulmonologic weaning centers, about $50 \%$ of all patients with initial weaning failure can be liberated from mechanical ventilation [2].

\footnotetext{
*Correspondence: t.platz@bdh-klinik-greifswald.de

'Presidium of the German Neurorehabilitation Society (Deutsche Gesellschaft für Neurorehabilitation, DGNR e.V.), Rheinbach, Germany

${ }^{2} \mathrm{BDH}-$ Klinik Greifswald, Neurorehabilitation . Ventilation and Intensive Care Spinal Cord Injury Unit, Karl-Liebknecht-Ring 26a, 17491 Greifswald, Germany Full list of author information is available at the end of the article
}

However, a substantial subset of patients in need for prolonged weaning treatment is also affected by neurodisabilities and requires the combination of prolonged weaning treatment and multi-professional neurorehabilitation to address their various needs for improving both their health, body functions, and autonomy with activities of daily living [5]. In a German cohort, $26 \%$ of 754 patients admitted for "early neurorehabilitation" were on mechanical ventilation commencing their neurological rehabilitation; their weaning rate from mechanical ventilation was $65 \%$ during their stay [4].

While there is a considerable need for such a specialized combined service with proven effectiveness, there is

(c) The Author(s). 2020 Open Access This article is licensed under a Creative Commons Attribution 4.0 International License, which permits use, sharing, adaptation, distribution and reproduction in any medium or format, as long as you give appropriate credit to the original author(s) and the source, provide a link to the Creative Commons licence, and indicate if changes were made. The images or other third party material in this article are included in the article's Creative Commons licence, unless indicated otherwise in a credit line to the material. If material is not included in the article's Creative Commons licence and your intended use is not permitted by statutory regulation or exceeds the permitted use, you will need to obtain permission directly from the copyright holder. To view a copy of this licence, visit http://creativecommons.org/licenses/by/4.0/. 
a lack of knowledge about such hospital capacities that are currently available in Germany.

The German Neurorehabilitation Society (Deutsche Gesellschaft für Neurorehabilitation, DGNR e.V.) conducted a survey among its members to document hospital capacities ("beds") for prolonged weaning for patients with neuro-disabilities that require simultaneous multiprofessional neurorehabilitation treatment ("neuro-weaning beds").

\section{Methods}

By email invitation end of December 2019 and a repeated invitation at the beginning of January 2020, 381 members of the DGNR were invited to participate in a short online survey. They were asked to answer two questions hosted on the platform invote.de (provided by Netzmanufaktur $\mathrm{GmbH}$, Theaterstraße 4, 01067 Dresden):

1. Number of "neuro-weaning beds" in their hospital

2. Combined question to indicate number of "neuroweaning beds", organizational background (acute care hospital versus rehabilitation facility), name of the hospital, and name of head of department.

By repeating the question for number of beds and by asking for more detailed (identifying) information, the validation of entries was sought to be promoted. In addition, society members were encouraged to make sure within their hospital by contact with their head of department that data entry was provided only once per hospital to prevent reporting in duplicate.

All entries were screened for validity. Based on hospital name and head of department name the location of each unit within one of 16 German Federal states was coded.

The number of "neuro-weaning beds" per federal state was divided by population statistics for that state as published by the German Federal Agency for Statistics [7] to obtain the rate of "neuro-weaning beds" per 1.000 .000 inhabitants.

Descriptive statistics were generated using the software package SAS.

\section{Results}

Sixty-nine of a total of 123 survey respondents indicated that their hospital provides capacities for combined prolonged weaning and neurorehabilitation ("neuro-weaning beds").

One entry was regarded as "invalid entry": The entry stated "135" (beds) without further information and was not used for the descriptive statistics (as stated below).

The 68 remaining units had a total of 1094 "neuroweaning beds", on average 16.1 beds (95\% confidence interval 12.6 to 19.6) with a range from 2 to 68 beds per organization. Given a total population of 82.792 thousand inhabitants in Germany [7] this statistic would imply a capacity of 13.2 "neuro-weaning beds" per $10^{6}$ inhabitants.

As a sensitivity analysis we further analyzed the subset of data from units that gave more detailed (identifying) information $(n=57)$. Collectively these units reported 871 "neuro-weaning beds" with on average 15.3 beds for prolonged weaning (95\% confidence interval 11.7 to 18.8) and a range from 2 to 68 beds per organization. Three of these units were specialized for health care in children and adolescents ( 22 beds), two units for people with spinal cord injury (12 beds).

The (subset of) units that reported "neuro-weaning beds" together with their identification served as basis to describe their distribution across federal states in Germany (see Table 1).

\section{Discussion}

This representative survey indicated substantial hospital capacities for combined prolonged weaning and neurorehabilitation with a total of 1094 "neuro-weaning beds" in Germany. For 871 of these "neuro-weaning beds" identifying information was available supporting the survey's validity.

As with any voluntary survey, there is a relevant risk of underreporting. Thus, the true number of "neuroweaning beds" in Germany is likely to be higher than the one reported here.

The number of "neuro-weaning beds" within individual reporting hospitals varies considerably (from 2 to 68 beds) with an average of 16 beds and a 95\% confidence interval ranging from 12 to 19 . This indicates both a central tendency for organizational size and substantial differences in organizational settings.

The analysis of the geographical distribution across federal states of Germany was based on the $80 \%$ of "neuro-weaning beds" reported with identifying information. Hence, this analysis suffers from an "incomplete data" bias and absolute numbers should be interpreted with great caution. The data nevertheless points to a huge variability of population-based density of "neuroweaning beds" (per $10^{6}$ inhabitants for German federal states) in Germany.

\section{Conclusions}

The survey generated a crude estimate of hospital capacities ("beds") for prolonged weaning from a mechanical ventilator for patients with neuro-disabilities that require simultaneous multi-professional neurorehabilitation treatment. The substantial variability in size of units and their geographical distribution warrants a more refined follow-up survey to learn about the setting and organizational structures of such units before further 
Table 1 Distribution of reported hospital capacities for combined prolonged weaning and neurorehabilitation across federal states in Germany

\begin{tabular}{llll}
\hline Federal state & $\begin{array}{l}\text { Number of } \\
\text { units }\end{array}$ & $\begin{array}{l}\text { Number } \\
\text { of beds }\end{array}$ & $\begin{array}{l}\text { Beds per } 10^{6} \\
\text { inhabitants }\end{array}$ \\
\hline Baden-Württemberg & 8 & 80 & 7.3 \\
Bayern & 8 & 138 & 10.6 \\
Berlin & 4 & 37 & 10.2 \\
Brandenburg & 5 & 85 & 33.9 \\
Bremen & 0 & & \\
Hamburg & 3 & 88 & 48.1 \\
Hessen & 5 & 114 & 18.3 \\
Mecklenburg-Vorpommern & 3 & 75 & 46.6 \\
Niedersachsen & 8 & 85 & 10.7 \\
Nordrhein-Westfalen & 4 & 46 & 2.6 \\
Rheinland-Pfalz & 2 & 21 & 5.2 \\
Saarland & 0 & & \\
Sachsen-Anhalt & 1 & 18 & 18.1 \\
Sachsen & 2 & 26 & 6.4 \\
Schleswig-Holstein & 3 & 53 & 18.3 \\
Thüringen & 1 & 5 & 2.3 \\
\hline
\end{tabular}

conclusions can be drawn. However, this survey already confirms the high relevance of these "neuro-weaning" capacities for the recovery from breathing failure and hence the avoidance of long-term intensive home care. The number of people in need for invasive long-term ventilation in Germany dramatically increased over the past 15 years to an estimate of currently 20.000 patients, implying additional health care costs of around 4 billion Euros per year [3]. It is estimated that approximately 10.000 patients with neuro-disabilities in need for weaning from mechanical ventilation can be taken care of each year with the capacity of 1094 "neuro-weaning beds" of this survey. Given a success rate of 65 to $75 \%$ $[4,6]$, they collectively might prevent an estimated 7000 new cases of long-term ventilation per year, let alone the other neurorehabilitation achievements in terms of disability reduction and re-gaining autonomy with activities of daily living.

\section{Abbreviations}

DGNR: Deutsche Gesellschaft für Neurorehabilitation e.V;; SBT: Spontaneous breathing trial

\section{Acknowledgements}

The help of Katherina Rupp, medical documentation assistance is gratefully acknowledged.

Group authorship (individual members of the author group):

Thomas Platz. BDH-Klinik Greifswald, Centre for Neurorehabilitation, Intensive and Ventilation Care, Spinal Cord Injury Unit; \& Neurorehabilitation Research Unit, University Medical Centre Greifswald, Greifswald, Germany Andreas Bender. Therapiezentrum Burgau \& Department of Neuroloy, Ludwig-Maximilians-University, Munich, Germany
Christian Dohle, MEDIAN Klinik Berlin-Kladow \& Center for Stroke Research Berlin, Charité - University Medicine Berlin, Berlin, Germany

Anna Gorsler, Kliniken Beelitz GmbH Neurologische Rehabilitationsklinik, Beelitz-Heilstätten, Germany

Stefan Knecht, Neurorehabilitation Center Meerbusch \& Rehabilitative Neurowissenschaften am Institut für Klinische Neurowissenschaften der Heinrich Heine Universität Düsseldorf, Germany

Joachim Liepert, Kliniken Schmieder Allensbach, Allensbach, Germany

Thomas Mokrusch, Rehazentrum Gernsbach, Gernsbach, Germany Michael Sailer, MEDIAN Klinik NRZ Magdeburg, An-Institut für Neurorehabilitation der OvG Universität Magdeburg, Magdeburg, Deutschland

\section{Authors' contributions}

TP collected, analyzed, and interpreted the data regarding "neuro-weaning beds" and wrote a first draft of the manuscript. All authors read and edited the manuscript, and approved the final manuscript.

\section{Authors' information}

Thomas Platz acts as president of the DGNR, Christian Dohle as president elect, Thomas Mokrusch as past president.

\section{Funding}

This work was supported by the BDH Bundesverband Rehabilitation e.V. (charity for neuro-disabilities) by a non-restricted personal grant to TP. The sponsors had no role in the decision to publish or any content of the publication.

\section{Availability of data and materials}

The datasets generated during this survey are not publicly available, since no consent to share the hospital-based information has been obtained. Confidential inspection of the data is possible at the site of the corresponding author on reasonable request.

Ethics approval and consent to participate

Not applicable.

\section{Consent for publication}

Not applicable.

\section{Competing interests}

The authors declare that they have no competing interests.

\section{Author details}

${ }^{1}$ Presidium of the German Neurorehabilitation Society (Deutsche Gesellschaft für Neurorehabilitation, DGNR e.V.), Rheinbach, Germany. ${ }^{2}$ BDH-Klinik Greifswald, Neurorehabilitation . Ventilation and Intensive Care . Spinal Cord Injury Unit, Karl-Liebknecht-Ring 26a, 17491 Greifswald, Germany.

${ }^{3}$ Neurorehabilitation Research Group, Universitätsmedizin Greifswald Greifswald, Germany.

Received: 10 March 2020 Accepted: 19 May 2020

Published online: 01 July 2020

\section{References}

1. Boles, J. M., Bion, J., Connors, A., Herridge, M., Marsh, C., Pearl, R., et al. (2007). Weaning from mechanical ventilation. The European Respiratory Journal, 29, 1033-1056.

2. Deutsche Gesellschaft für Pneumologie und Beatmungsmedizin e.V. (DGP) (2019). S2k guideline "prolongiertes weaning". https://www.awmf.org/ leitlinien/detail/l/020-015.html. Accessed 3 Feb 2020.

3. Köhler, D. (2019). Tremendous increase of home care in ventilated and tracheostomized patients - reasons, consequences, solutions. Deutsche Medizinische Wochenschrift, 144, 282-285.

4. Pohl, M., Bertram, M., Bucka, C., Hartwich, M., Jöbges, M., Ketter, G., Leineweber, B., Mertl-Rötzer, M., Nowak, D. A., Platz, T., Rollnik, J. D., Scheidtmann, K., Thomas, R., von Rosen, F., Wallesch, C. W., Woldag, H., Peschel, P., \& Mehrholz, J. (2016). Rehabilitationsverlauf von Patienten in der neurologisch-neurochirurgischen Frührehabilitation: Ergebnisse einer multizentrischen Erfassung im Jahr 2014 in Deutschland. Nervenarzt, 87, 634-644. 
5. Rollnik, J. D., Adolphsen, J., Bauer, J., Bertram, M., Brocke, J., Dohmen, C., Donauer, E., Hartwich, M., Heidler, M. D., Huge, V., Klarmann, S., Lorenzl, S., Lück, M., Mertl-Rötzer, M., Mokrusch, T., Nowak, D. A., Platz, T., Riechmann, L., Schlachetzki, F., von Helden, A., Wallesch, C. W., Zergiebel, D., \& Pohl, M. (2017). Prolonged weaning during early neurological and neurosurgical rehabilitation: S2k guideline published by the Weaning Committee of the German Neurorehabilitation Society (DGNR). Nervenarzt, 88, 652-674.

6. Schmidt, S. B., Boltzmann, M., Bertram, M., Bucka, C., Hartwich, M., Jöbges, M. , Ketter, G., Leineweber, B., Mertl-Rötzer, M., Nowak, D. A., Platz, T., Scheidtmann, K., Thomas, R., Rosen, F. V., Wallesch, C. W., Woldag, H., Peschel, P., Mehrholz, J., Pohl, M., \& Rollnik, J. D. (2018). Factors influencing weaning from mechani-cal ventilation in neurological and neurosurgical early rehabilitation patients. European Journal of Physical and Rehabilitation Medicine, 54, 939-946.

7. Statistisches Bundesamt (2019). Statistisches Jahrbuch 2019, Kapitel 2

Bevölkerung, Familien, Lebensformen. https://www.destatis.de/DE/Themen/

Querschnitt/Jahrbuch/statistisches-jahrbuch-aktuell.html. Accessed 3 Feb 2020.

\section{Publisher's Note}

Springer Nature remains neutral with regard to jurisdictional claims in published maps and institutional affiliations.

Ready to submit your research? Choose BMC and benefit from:

- fast, convenient online submission

- thorough peer review by experienced researchers in your field

- rapid publication on acceptance

- support for research data, including large and complex data types

- gold Open Access which fosters wider collaboration and increased citations

- maximum visibility for your research: over $100 \mathrm{M}$ website views per year

At $\mathrm{BMC}$, research is always in progress.

Learn more biomedcentral.com/submissions 